\title{
家兔胚胎在液氮 $\left(-196^{\circ} \mathrm{C}\right)$ 冷冻保存后的活力
}

谭丽玲 白琴华 袁义达 陈秀兰

(中国科学院遗传研究所)

哺乳动物胚胎超低温 $\left(-196^{\circ} \mathrm{C}\right)$ 冷冻保存于 1972 年首先在小鼠获得成功 (Whittingham, Leibo and Mazur, 1972)[1]. 以后, 牛 (Wilmut and Rowson, 1973), 羊 (Willadsen, Polge, Rowson and Moor, 1974)，兔 (Whittingham and Adams，1974）和大鼠 (Whittingham, 1975) 的胚胎相继冷冻成功. 应用冷冻保存技术不但能根据需要随时进行胚胎移植, 而且还可以进 行胚胎运输和建立基因库一一长期保存有价值的遗传材料和珍贵的品种资源. 它和冷冻精液 一样在家畜的良种育中有着重大的意义. 因此, 近年来这项技术发展很快.一些国家如英 国、加拿大、澳大利亚、法国、西德、美国、新西兰和丹麦等已建立家畜胚胎移植公司，在生产实 际中开始应用超低温冷冻保存技术并成功地进行国际间长距离胚胎运输.

我国家畜胚胎移植成功 (羊,牛) 后 ${ }^{[2,3]}$, 现正开始进行超低温冷冻保存的研究. 本试验的 目的是用兔胚为材料, 探究哺乳动物胚胎超低温冷冻保存的方法和活力. 在我国现有的设备 条件基础上为今后哺釈动物包括家畜胚胎冷冻保存提供依据.

\section{材料和方法}

试验用的供体和受体母兔为大耳白、青紫蓝和黑兔. 受体与结扎输精管后,经反复采精证 实是不育的公兔交配. 供体用 FSH 和 LH 处理以诱发超数排卵,在配种后 40-48 小时或大约 65 小时行手术取卵, 收集到 8-16 细胞期或桑椹期胚胎. 冲卵液采用改良的杜氏磷酸缓冲液 (Dulbecco's PBS), 加入 $50 \%$ 灭活的兔血清. 冷冻保护剂用二甲基亚硐 (DMSO), 添加和稀释 均采用三步法. 冷㑈前分三次加入 $2.5 M-\mathrm{DMSO}$, 每次 0.05 毫开, 间隔 10 分钟, 使 DMSO 的最 终浓度为 $1.5 \mathrm{M}$. 胚胎在此浓度下进行冷冻. 从室温降到 $-5^{\circ} \mathrm{C}$ 的速率为 $1^{\circ} \mathrm{C} /$ 分, 在 $-5^{\circ} \mathrm{C}$ 诱发结晶. 从 $-5^{\circ} \mathrm{C}$ 降到 $-70^{\circ} \mathrm{C}$ 的速率是 $0.26-0.43^{\circ} \mathrm{C} /$ 分. 然后直接放人液氮 $\left(-196^{\circ} \mathrm{C}\right)$ 内保存. 解冻时从液氮中取出胚胎, 直接放入干水内 $\left(-79^{\circ} \mathrm{C}\right)$ 平衡 $2-3$ 分钟后, 移人 $-70^{\circ} \mathrm{C}$ 酒精浴内以大约 4-10 $0^{\circ} \mathrm{C} /$ 分的速率升温到 $0^{\circ} \mathrm{C}$, 然后放到 $37^{\circ} \mathrm{C}$ 的水浴内. 同样间隔 10 分钟 分三次加人 $0.2 、 0.2 、 0.4$ 毫升 PBS 以稀释 DMSO 的浓度. 最后把胧胎移到新鲜的 PBS 内并洗 $2-3$ 遍.

解冻并除去 DMSO 后的胚胎,经形态上初步鉴定后, 立即进行培养或移植以确定其活力. 对所用的胚胎没有特别挑选，在培养或移植的胚胎中有一部分经鉴定形态是不正常的. 体外 培养时胚胎在含有 $5 \% \mathrm{CO}_{2}$ 的空气中在 $37{ }^{\circ} \mathrm{C}$ 下培养 $1-2$ 天. 所用培养液见表 1 和 3 . 移植 时肧胎均系手术移入输卵管内.

本文 1980 年 1 月 21 日收到。 


\section{结 果 和 讨 论}

兔胚超低温冷冻一解冻后培养和移植的活力见表 1 和 2 . 结果表明,在 $1.5 M-D M S O$ 下用 $0.26-0.43^{\circ} \mathrm{C} /$ 分的速率冷冻和用 $4-10^{\circ} \mathrm{C} /$ 分的速率解冻的 $8-16$ 细胞期和桑椹期胚胎仍能

表 1 兔胚在液氮 $\left(-196^{\circ} \mathrm{C}\right)$ 冷冻保存后体外培养一天的活力

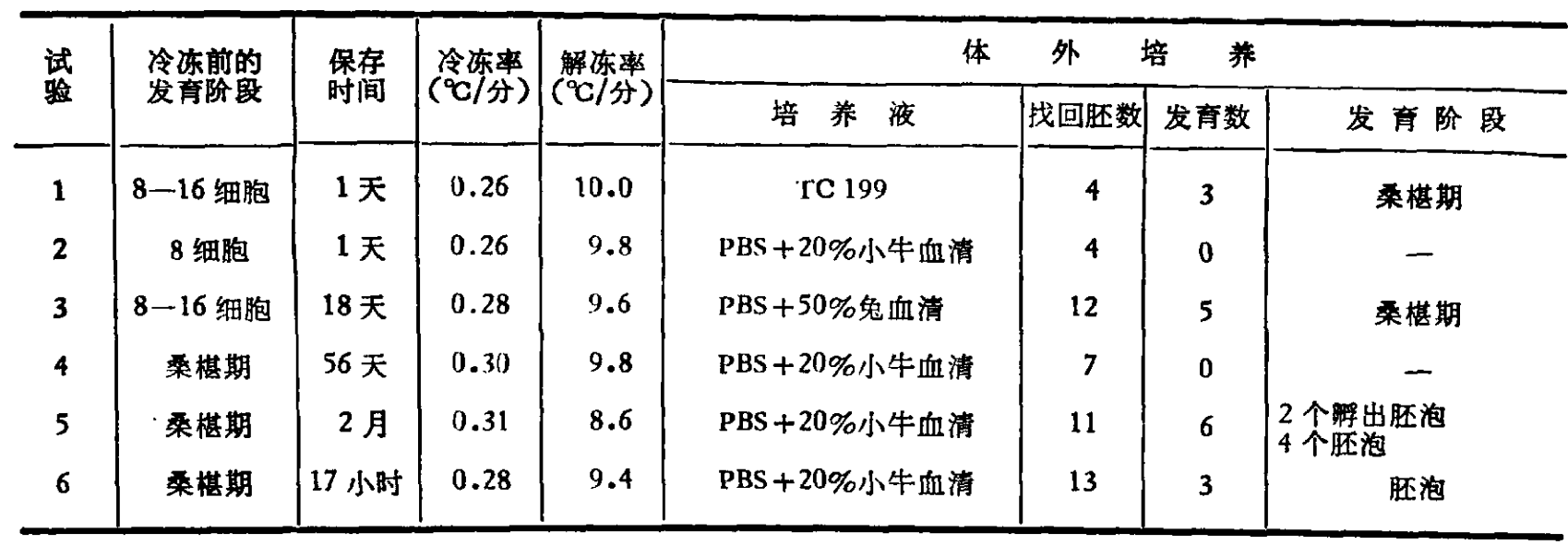

存活. 这与文献报道相符 ${ }^{[4-7]}$. 在液氮中保存 17 小时到 2 个月的兔胚在培养后找回的 51 个 中有 17 个继续发育. 保存 1-8.5 天的兔胚, 有 96 个移给 8 头受体，其中有 4 头共生下 9 只

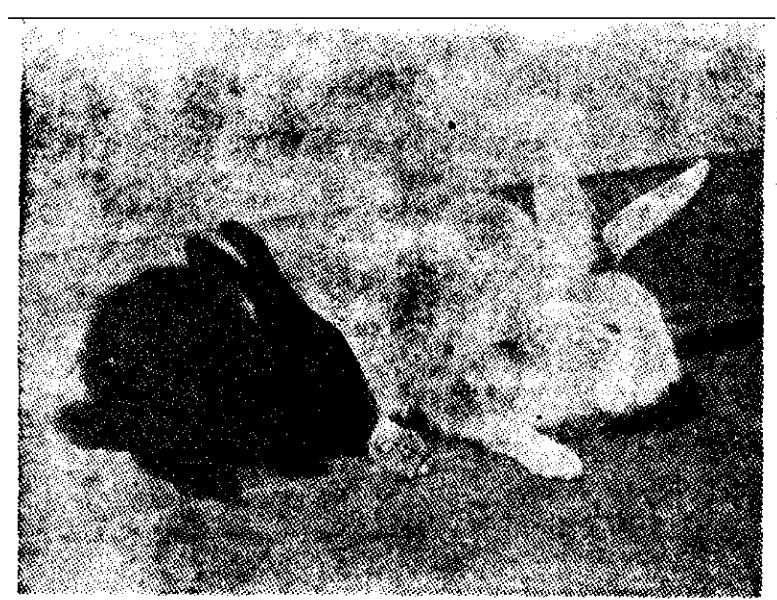

图 1 受体 79 号(白兔)和它所生的一只小黑兔

小兔是由在供体 (黑兔) 中取得并在液氮 $\left(-196^{\circ} \mathrm{C}\right.$ ) 保存 8.5 天

后移入受体的一个胚胎 (8一细胞期)发育而来的

表 2 兔胚在液氮 $\left(-196^{\circ} \mathrm{C}\right)$ 冷冻保存后移植到受体的活力

\begin{tabular}{|c|c|c|c|c|c|c|c|}
\hline 试验 & 受体号 & $\begin{array}{l}\text { 移入 } \\
\text { 还数 }\end{array}$ & 发育阶段 & $\begin{array}{l}\text { 保存时间 } \\
\text { (天) }\end{array}$ & $\begin{array}{l}\text { 冷冻率 } \\
\left({ }^{\circ} \mathrm{C} / \text { 分 }\right)\end{array}$ & $\begin{array}{l}\text { 解冻事 } \\
\left({ }^{\circ} \mathrm{C} / \text { 分 }\right)\end{array}$ & 移 植 结 果 \\
\hline 1 & $\begin{array}{r}56 \\
268\end{array}$ & $\begin{array}{l}19 \\
14\end{array}$ & $\begin{array}{l}16 \text { 细胞 } \\
16 \text { 纽胞 }\end{array}$ & $\begin{array}{l}6 \\
6\end{array}$ & $\begin{array}{l}0.31 \\
0.31\end{array}$ & $\begin{array}{l}7.0 \\
7.0\end{array}$ & $\begin{array}{l}\text { 没辇(消瘦,移卵后 } 20 \text { 天死亡) } \\
\text { 奼娠 } 21 \text { 天流产 } 6-7 \text { 个胎儿 }\end{array}$ \\
\hline 2 & $1-7713$ & 12 & 16 细胞 & 1 & 0.43 & 4.2 & 娃娠 19 天流产 1 个胎儿 \\
\hline 3 & 62 & 8 & $8-16$ 细胞 & 2.5 & 0.38 & 8.0 & $\begin{array}{c}\text { 产下 } 3 \text { 只小兔(二只被吃, 二 } \\
\text { 只难产,生下即死) }\end{array}$ \\
\hline 4 & $\begin{array}{r}8 \\
659\end{array}$ & $\begin{array}{r}8 \\
10\end{array}$ & $\begin{array}{r}8 \text { 细胞 } \\
8-16 \text { 细胞 }\end{array}$ & 1 & $\begin{array}{l}0.30 \\
0.30\end{array}$ & $\begin{array}{l}4.5 \\
4.5\end{array}$ & $\begin{array}{l}\text { 产 } 3 \text { 只小兔 } \\
1 \text { 只小兔 }\end{array}$ \\
\hline 5 & $\begin{array}{l}79 \\
80\end{array}$ & $\begin{array}{l}1.3 \\
12\end{array}$ & $\begin{array}{l}8 \text { 细胞 } \\
8 \text { 细胞 }\end{array}$ & $\begin{array}{l}8.5 \\
6.5\end{array}$ & $\begin{array}{l}0.30 \\
0.28\end{array}$ & $\begin{array}{l}4.1 \\
4.1\end{array}$ & $\begin{array}{l}\text { 产 } 2 \text { 只小兔 } \\
\text { 没否(移卵后24天肠梗阻死亡) }\end{array}$ \\
\hline
\end{tabular}


小兔 (图 1), 另两头分别在妊娠 19 和 21 天后流产. 其余两头未受孕,分别在输卵后 20 和 24 天死亡.

在表 2 没有列出的其余一些陈胚移植试验没有胚胎存活. 特别是移入桑椹期胚胎的受体 没有一头受㔔. 推测其原因,除本试验所用受体多作过一至数次手术, 体况不佳外, 还可能是 桑椹期胚胎虽从输卵管收集到, 但即将进入子宫, 而移卵时又重新从繖部移入, 输卵管环境对 其继续发育可能不适宜.

表 3 小四胚胎在液氮 $\left(-196^{\circ} \mathrm{C}\right)$ 冷冻保存后体外培养的活力

\begin{tabular}{|c|c|c|c|c|c|c|c|c|c|}
\hline \multirow{2}{*}{ 试验 } & \multirow{2}{*}{$\begin{array}{c}\text { 冷冻前 } \\
\text { 发育阶段 }\end{array}$} & \multirow{2}{*}{$\begin{array}{l}\text { 保存 } \\
\text { 时间 }\end{array}$} & \multirow{2}{*}{$\begin{array}{l}\text { 冷冻率 } \\
\left({ }^{\circ} \mathrm{C} / \text { 分 }\right)\end{array}$} & \multirow{2}{*}{$\begin{array}{l}\text { 解㑈率 } \\
\text { ( } \mathrm{C} / \text { 分) }\end{array}$} & \multicolumn{5}{|c|}{ 体 外培 养 } \\
\hline & & & & & 培养 液 & 培养天数 & 找回胚数 & 发育数 & 发育阶段 \\
\hline 1 & 8 细胞 & 17 小时 & 0.26 & 8.6 & 惠顿 $+30 \%$ 小牛血清 & 1.5 & 6 & 2 & 委椹期 \\
\hline \multirow{3}{*}{2} & 2 细胞 & 1 天 & 0.26 & 9.8 & 惠顿 $+20 \%$ 小牛血清 & $\mathbf{I}$ & 4 & 2 & 1 个 6 细胞 \\
\hline & 4 细胞 & 1 天 & 0.26 & 9.8 & 惠顿 +20\%小牛血清 & 1 & 10 & 0 & \\
\hline & 8 细胞 & 1 天 & 0.26 & 9.8 & 惠顿 $+20 \%$ 小牛血清 & 2 & 4 & 3 & $\begin{array}{l}1 \text { 个桑椹肧 } \\
2 \text { 个胚泡 }\end{array}$ \\
\hline 3 & 8 细胞 & 6.5 天 & 0.28 & 4.1 & PBS + 50\% 兔血清 & 2 & 4 & 2 & 桑椹期 \\
\hline
\end{tabular}

本试验附带还用见栓两天后取到的 2-8 细胞期小国胚胎进行超低温冷冻保存。解冻后培 养的活力见表 3. 结果表明,小鼠早期 $\left(2-8\right.$ 细胞期)胚胎在 $1.5 M-D M S O$ 下,以 $0.26-0.28{ }^{\circ} \mathrm{C} /$ 分速率冷冻和以 $4-10^{\circ} \mathrm{C} /$ 分速率解冻后, 体外培养仍能正常发育. 这与文献报道也是一致 的 ${ }^{[1]}$.

致谢：陕西省动物研究所贾敬肖同志参加部分工作.

\section{考文献}

[ 1 ] Whittingham, D. G., Leibo, S. P. \& Mazur, P., Science, 178 (1972), 411.

[2] 中国科学院遭传研究所等, 遭传与育种, 1975, 3: 8-9.

[ 3 ] 中国科学院遗传研究所等, 家育䇣殖及人工授精(全国第一届家育策殖及人工授精会议论文选编), 1979.

[ 4 ] Bank, H. \& Maurer, R. R., Expl. Cell Res., 89 (1974),188-196.

[ 5 ] Tsunoda, Y. \& Sugie, T., J. Reprod. Fert., 49 (1977), 173-174.

[ 6 ] Tsunoda, Y. \& Sugie, T., J. Reprod, Fert., 50 (1977), 123-124.

[ 7] Whittingham, D. G. \& Adams, C. E., Cryobiology, 11 (1974), 560. 